\title{
Fettavleiringer i hjernepulsårene - en ultralydstudie
}

Nicola Logallo, ansatt ved Institutt for klinisk medisin, Universitetet i Bergen, disputerte 7. desember 2012 for ph.d.-graden ved Universitetet i Bergen med avhandlingen:

\section{Intracranial atherosclerosis - An ultra- sound study}

Hjerneinfarkt er forårsaket av blodpropp som stenger blodtilførselen til hjernen. Blodproppen kommer som oftest fra hjertet eller fra fettavleiringer på innsiden av halspulsårene. En annen årsak er intrakraniell aterosklerose eller intrakranielle stenoser.

Hjernens pulsårer ble undersøkt ved hjelp av ultralyd og CT og MR hos pasienter med hjerneinfarkt. Studien viser at $8 \%$ av alle pasienter med hjerneinfarkt har intrakranielle stenoser og at disse er årsaken til hjerneinfarkt i 5\% av tilfellene.
Stenosegraden gjenspeiler pasientens risiko for et nytt infarkt og er avgjørende for valg av behandlingen. Ultralyd er en rimelig, skånsom og pålitelig metode for å oppdage stenoser i hjernens pulsårer, men kriteriene som i dag brukes til å vurdere stenosegraden er unøyaktige. Studien har utarbeidet nye kriterier og viser, at de nye kriteriene er mer nøyaktige enn de nåværende.

Studien har også undersøkt uløste tekniske problemer relatert til ultralyd, kontrastmidler i forbindelse med ultralyd og nye ultralydapplikasjoner, som kan forbedre diagnostikken av hjernens perfusjon.

Samlet har studien økt kunnskap om mekanismer bak hjerneinfarkt og bekreftet betydningen av ultralyd i diagnose og utredning av pasienter med hjerneinfarkt.

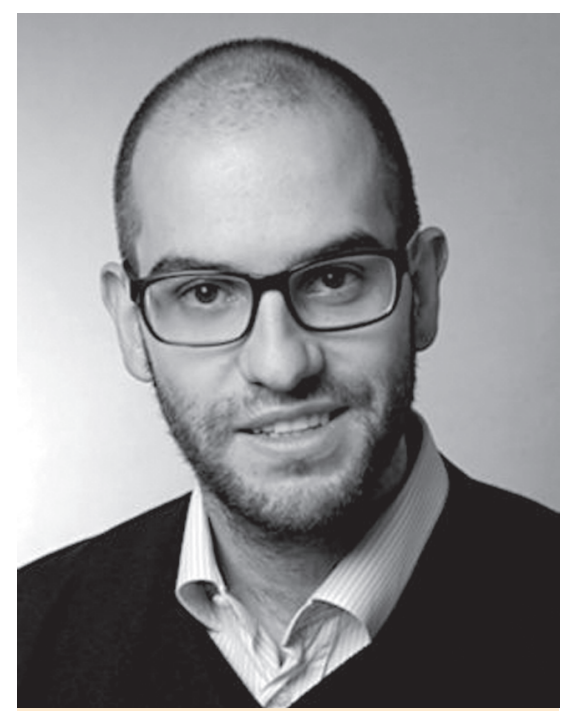

Nicola Logallo Foto: Anne Sidsel Herdlevær 